J. Perinat. Med. 17 (1989) 259

\title{
Growth and development at the age of 1.5 years in children with maternal hypertension
}

\author{
Anneli Martikainen
}

Department of Paediatrics, University Central Hospital, Kuopio, Finland

\section{Introduction}

Hypertension is still one of the commonest complications of pregnancy. With declining peri- and neonatal mortality more delicate and far-sighted measures are needed to evaluate the outcome of infants. Hypertension in pregnancy is associated with retarded intrauterine growth (IUGR) and an altered neurological condition of the newborn $[1,10,13,24]$. Studies on the further development and growth of these children are few and the results contraversial. Some describe neurodevelopmental delay $[14,17,25]$ and poor weight gain during the first year of life [25] by comparison with infants born to normotensive (NT) mothers, but others contradict these findings [7, $21,24,26]$. Others also report more major neurological handicaps in infants born to hypertensive mothers $[25,26]$ - findings again not always supported [7, 24]. Epidemiological studies show increased frequencies of maternal pre-eclampsia in cases of children with cerebral palsy [4]. Prematurity and IUGR apart we have observed that maternal hypertension does cause differences in the neurological condition of neonates by comparison with infants born to normotensive mothers [100.

Because of these differences, a longer follow-up was indicated. The aim of the present study was to evaluate the growth and development of hypertensive children at the corrected age of $\mathbf{1 . 5}$ years.

\section{Definitions and abbreviations}

HT = hypertensive: blood pressure over 140/ $90 \mathrm{mmHg}$ when measured twice at intervals of not less than 6 hours during pregnancy or delivery

\section{Curriculum vitae}

ANNELI MarTikainen, M. D., was born in Paltamo, Finland. She studied medicine at the University of Oulu and was qualified in 1971. She took her degree as a specialist in pediatrics in 1981 at Kuopio University Central Hospital and is now working there in the Neonatological Unit.

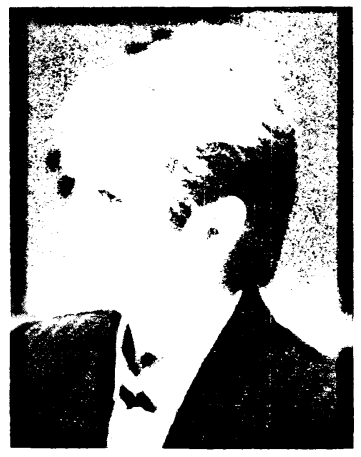

She has examined the neurodevelopmental outcome of infants with respect to various perinatal risk factors.

\section{NT = normotensive}

$\mathrm{HCP}=$ chronic hypertension: hypertension diagnosed before the 24th week of pregnancy

PIH = hypertension induced by pregnancy: hypertension diagnosed at or after the 24 th week of pregnancy

PRE = pre-eclampsia: hypertension and proteinuria over $0.3 \mathrm{~g} / \mathrm{day}$. In this study the HCP and PIH groups do not include cases with PRE.

pre- $=$ birth before the beginning of the 37 th term week of gestation

SGA = small for gestational age: birth weight, birth length or ponderal index more than 2 SDs below the mean for the gestational age concerned. The ponderal index is the cube root of body weight times 100 divided by body length 


\section{Material and methods}

In the 22 months from 1984 to 1986,561 babies were born alive to HT mothers (representing $15 \%$ of all pregnancies) in Kuopio University Central Hospital. All preterm children, all SGA children and a sample of full-term AGA children born to HT and NT mothers during the study period were included at birth. Of these, $81 \%$ (504 children) were examined at the age of 1.5 years. Drop-outs from the study were equally distributed in all groups. The HT groups comprised 104 boys and 97 girls and the NT groups 145 boys and 158 girls. To avoid the confounding nature of prematurity and IUGR on development, comparisons between HT and NT children were first made among preterm AGA, then among preterm SGA, full-term SGA and finally full-term AGA children. The distributions of sex, means of gestational ages, birth weights, lengths and head circumferences did not differ between pairs of groups (table I).

Reduced optimality scores for characterisation of prepartum, partum and neonatal events were summed according to Prechtl and Kyllerman [8, 19]. These and detailed obstetric and neonatal data are presented in table II.
All children were assessed by the author at the corrected age of 1.5 years \pm 2 weeks at the outpatient clinic in the presence of one or both parents. Along with confirmation of the examination date parents received a questionnaire including developmental items and age at which the baby pulled itself to a standing position, learned to walk unsupported and said the first word.

If on examination the child was not in good health and alert, the assessment was postponed to another time or day. Behaviour during the examination was recorded as cooperative, resistant and frightened, or unable to concentrate.

The schedule included physical examination, measurement of growth (table I) and neurodevelopmental items in accordance with various reports $[3,6,9]$. General guidelines for neurological assessment were adapted from those of Illingworth [6]. Details of the neurological assessment were mainly based on items in the Denver Developmental Screening Test, which is widely used in Finland [3]. The drawing test described by Lundberg [9] was used because it is considered as a good predictor of subsequent fine motor development. Vision was tested using objects

Table I. Means (SD) of gestational age, weight, height and head circumference at birth and at 1.5 years of corrected age in hypertensive (HT) and normotensive (NT) groups

\begin{tabular}{|c|c|c|c|c|c|c|c|c|}
\hline & \multicolumn{2}{|c|}{ Preterm AGA } & \multicolumn{2}{|c|}{ Preterm SGA } & \multicolumn{2}{|c|}{ Full-term AGA } & \multicolumn{2}{|c|}{ Full-term SGA } \\
\hline & $\begin{array}{l}\mathrm{HT} \\
\mathrm{n}=33\end{array}$ & $\begin{array}{l}\text { NT } \\
\mathrm{n}=111\end{array}$ & $\begin{array}{l}\mathrm{HT} \\
\mathrm{n}=25\end{array}$ & $\begin{array}{l}\mathrm{NT} \\
\mathrm{n}=17\end{array}$ & $\begin{array}{l}\mathrm{HT} \\
\mathrm{n}=125\end{array}$ & $\begin{array}{l}\mathrm{NT} \\
\mathrm{n}=121\end{array}$ & $\begin{array}{l}\mathrm{HT} \\
\mathrm{n}=18\end{array}$ & $\begin{array}{l}\mathrm{NT} \\
\mathrm{n}=54\end{array}$ \\
\hline Gestational age (weeks) & 34.6 & 34.2 & 32.8 & 31.6 & 39.6 & 39.7 & 39.3 & 39.4 \\
\hline SD & 1.8 & 1.9 & 2.4 & 3.0 & 1.6 & 1.3 & 1.5 & 1.6 \\
\hline \multicolumn{9}{|l|}{ Birth } \\
\hline weight (g) & 2376 & 2475 & 1492 & 1276 & 3513 & 3571 & 2636 & 2617 \\
\hline SD & 536 & 550 & 458 & 413 & 525 & 454 & 548 & 456 \\
\hline height $(\mathrm{cm})$ & 45.7 & 46.0 & 40.2 & 39.0 & 50.5 & 50.7 & 47.3 & 46.9 \\
\hline SD & 2.4 & 2.7 & 3.3 & 3.1 & 2.2 & 1.9 & 2.3 & 2.7 \\
\hline head circ. $(\mathrm{cm})$ & 32.1 & 32.2 & 29.2 & 27.8 & 34.8 & 34.8 & 32.6 & 33.1 \\
\hline SD & 1.8 & 2.2 & 2.7 & 2.6 & 1.3 & 1.4 & 1.5 & 1.3 \\
\hline \multicolumn{9}{|l|}{1.5 years } \\
\hline weight $(\mathrm{kg})$ & 11.3 & 11.4 & 9.5 & 10.2 & 11.5 & 11.5 & 10.6 & 10.0 \\
\hline SD & 1.3 & 1.3 & 1.3 & 1.6 & 1.3 & 1.5 & 1.3 & 1.0 \\
\hline height $(\mathrm{cm})$ & 81.3 & 82.3 & 78.8 & 80.2 & 82.1 & 82.2 & 80.2 & 79.1 \\
\hline SD & 2.9 & 2.8 & 4.1 & 2.8 & 2.5 & 3.1 & 2.9 & 2.7 \\
\hline head circ. $(\mathrm{cm})$ & 48.3 & 48.4 & 47.2 & 47.4 & 48.4 & 48.2 & 47.3 & 46.9 \\
\hline SD & 1.9 & 1.5 & 1.4 & 1.2 & 1.3 & 1.4 & 1.2 & 1.4 \\
\hline
\end{tabular}


Table II. Obstetric and neonatal history in hypertensive (HT) and normotensive (NT) AGA and SGA groups

\begin{tabular}{|c|c|c|c|c|c|c|c|c|}
\hline & \multicolumn{2}{|c|}{ Preterm AGA } & \multicolumn{2}{|c|}{ Preterm SGA } & \multicolumn{2}{|c|}{ Full-term AGA } & \multicolumn{2}{|c|}{ Full-term SGA } \\
\hline & $\begin{array}{l}\mathrm{HT} \\
\mathrm{n}=33\end{array}$ & $\begin{array}{l}\text { NT } \\
\mathrm{n}=111\end{array}$ & $\begin{array}{l}\mathrm{HT} \\
\mathrm{n}=25\end{array}$ & $\begin{array}{l}\text { NT } \\
n=17\end{array}$ & $\begin{array}{l}\mathrm{HT} \\
\mathrm{n}=125\end{array}$ & $\begin{array}{l}\mathrm{NT} \\
\mathrm{n}=121\end{array}$ & $\begin{array}{l}\mathrm{HT} \\
\mathrm{n}=18\end{array}$ & $\begin{array}{l}\mathrm{NT} \\
\mathrm{n}=54\end{array}$ \\
\hline $\begin{array}{l}\text { Mean prepartal scores } \\
\text { (range } 0-12) \pm S D\end{array}$ & $\begin{array}{l}1.8 \\
1.4\end{array}$ & $\begin{array}{l}1.9 \\
1.4\end{array}$ & $\begin{array}{l}1.5 \\
1.1\end{array}$ & $\begin{array}{l}2.5 \\
1.6\end{array}$ & $\begin{array}{l}1.2 \\
1.1\end{array}$ & $\begin{array}{l}1.1 \\
1.1\end{array}$ & $\begin{array}{l}1.4 \\
1.5\end{array}$ & $\begin{array}{l}1.4 \\
1.2\end{array}$ \\
\hline $\begin{array}{l}\text { Mean partal scores } \\
\text { (range } 0-13) \pm S D\end{array}$ & $\begin{array}{l}2.4 \\
1.0\end{array}$ & $\begin{array}{l}2.4 \\
1.1\end{array}$ & $\begin{array}{l}2.2 \\
0.8\end{array}$ & $\begin{array}{l}2.7 \\
1.0\end{array}$ & $\begin{array}{l}2.3 \\
1.2\end{array}$ & $\begin{array}{l}2.1 \\
1.0\end{array}$ & $\begin{array}{l}2.4 \\
1.0\end{array}$ & $\begin{array}{l}2.5 \\
1.1\end{array}$ \\
\hline $\begin{array}{l}\text { Mean neonatal scores } \\
\text { (range } 0-7 \text { ) } \pm \text { SD }\end{array}$ & $\begin{array}{l}1.9 \\
1.5\end{array}$ & $\begin{array}{l}1.9 \\
1.6\end{array}$ & $\begin{array}{l}3.4 \\
1.2\end{array}$ & $\begin{array}{l}3.4 \\
1.2\end{array}$ & $\begin{array}{l}0.6 \\
1.0\end{array}$ & $\begin{array}{l}0.3 \\
0.5\end{array}$ & $\begin{array}{l}1.1 \\
1.2\end{array}$ & $\begin{array}{l}0.8 \\
1.2\end{array}$ \\
\hline $\begin{array}{l}\text { Mean maternal age (yrs) } \\
\pm S D\end{array}$ & $\begin{array}{r}28.3 \\
5\end{array}$ & $\begin{array}{r}28.8 \\
5\end{array}$ & $\begin{array}{r}30.6 \\
7\end{array}$ & $\begin{array}{r}31.8 \\
6\end{array}$ & $\begin{array}{r}30.0 \\
6\end{array}$ & $\begin{array}{r}28.2 \\
5\end{array}$ & $\begin{array}{r}26.5 \\
5\end{array}$ & $\begin{array}{r}26.9 \\
4\end{array}$ \\
\hline $\begin{array}{l}\text { Mean maternal diastolic } \\
\text { pressure }(\mathrm{mmHg}) \pm \mathrm{SD}\end{array}$ & $\begin{array}{r}109 \\
11\end{array}$ & $\begin{array}{r}80 \\
8\end{array}$ & $\begin{array}{r}110 \\
12\end{array}$ & $\begin{array}{r}83 \\
6\end{array}$ & $\begin{array}{r}104 \\
8\end{array}$ & $\begin{array}{r}82 \\
7\end{array}$ & $\begin{array}{r}102 \\
8\end{array}$ & $\begin{array}{r}81 \\
7\end{array}$ \\
\hline Primiparae, \% & 67 & 48 & 64 & 29 & 56 & 41 & 72 & 64 \\
\hline Vaginal bleeding, \% & 6 & 27 & 4 & 48 & 9 & 12 & 6 & 12 \\
\hline $\begin{array}{l}\text { Premature rupture of } \\
\text { membranes, \% }\end{array}$ & 18 & 23 & 8 & 29 & 6 & 4 & 6 & 6 \\
\hline Caesarean section, $\%$ & 61 & 34 & 80 & 67 & 28 & 8 & 39 & 15 \\
\hline 1 min Apgar score $<6, \%$ & 12 & 13 & 28 & 35 & 8 & 3 & 11 & 0 \\
\hline Assisted ventilation, $\%$ & 12 & 20 & 40 & 53 & 2 & 0 & 6 & 2 \\
\hline Hypoglycaemia, \% & 6 & 0 & 20 & 6 & 2 & 0 & 6 & 4 \\
\hline Septic infection, $\%$ & 0 & 1 & 8 & 6 & 0 & 0 & 0 & 2 \\
\hline Convulsion, $\%$ & 14 & 10 & 12 & 12 & 2 & 0 & 6 & 2 \\
\hline Abnormal cerebral scan, $\%$ & 00 & 5 & 8 & 12 & 0 & 0 & 0 & 0 \\
\hline
\end{tabular}

$0.1-10 \mathrm{~cm}$ in diameter held $30 \mathrm{~cm}$ away from the child. Hearing was tested using a standardized bell. Individual items and neurodevelopmental scores analysed in this report are shown in table III.

Neurodevelopmental performance was classified as suspect if any of the following subscores was lower than the 10th centile of that of the NT full-term AGA group: building a tower of two cubes, scribbling with a crayon, pointing to one coloured picture or to one body part, saying one word and walking forwards independently. If the child had cerebral palsy, hydrocephalus or had had convulsions, it was classified as neurologically abnormal.

Statistical methods: Student's two-tailed t-test and the chi-squared test were used for compar- isons between pairs of groups and the KruskalWallis test for comparisons between more than two groups [22]. If further information about intergroup relationships in the Kruskal-Wallis test was needed the Mann-Whitney test was used with Bonferonni correction.

Stepwise discriminant analysis [16] was done separately for preterm and full-term infants and was used to determine the contribution of several simultaneous factors to neurodevelopmental outcome. Each of the five neurodevelopmental optimality scores was examined separately with reduced optimality scores for prepartal, partal and neonatal events and intrauterine growth retardation and sex. The normality of distribution of all scores was first examined using the Kolmogoroff-Smirnoff test [22]. 
Table III. Neurological developmental items and their scoring to give five optimality scores used in the assessment of children at 1.5 years

1) Gross motor performance

$(0-12)$

- walking:

0 could not walk

1 could walk supported by a person

2 could walk holding on to furniture

3 could walk unsupported

4 could walk 3 steps backwards

- running: $\quad 0$ could not run

2 could run

- walking up stairs: $\quad 0$ could not walk up 3 steps

1 could crawl up 3 steps

2 could walk up 3 steps by holding on to someone's hand

3 could walk up 3 steps unaided

- walking down stairs: $\quad 0$ could not walk down 3 steps

1 could crawl down 3 steps

2 could crawl down 3 steps by holding on to someone's hand

3 could crawl down 3 steps unaided

2) Fine motor performance $(0-20)$

- could build a tower of: $\quad 0 \quad 0$ cubes

12 cubes

24 cubes

36 cubes

48 cubes

- could put $0-5$ different objects through correspondingly shaped holes:

- drawing test:

drawing:

0 could not scribble

2 could scribble

4 could imitate vertical line

type of grasp:

0 tong/toptong grasp

1 palmar grasp from above

2 with stabilizing index finger

3 palmar grasp around shaft

4 with stabilizing index finger

5 web-of-thumb grasp

position of arm: $\quad 0$ supinated

1 overpronated

2 pronated

3) Visual and auditory perception (0-24)

- pictures: $\quad 0-5$ : coudl points to $0-5$ coloured pictures

$0-5$ : could name $0-5$ coloured pictures

$0-5$ : could point to $0-5$ silhouette (DDST) pictures

$0-5$ : could name $0-5$ silhouette (DDST) pictures

- pointing to body parts as reported by parents:

$0 \quad 0$ body parts

12 body parts

24 body parts

36 body parts

48 body parts 
Table III. Continued

4) Speaking as reported by parents $(0-13)$

$\begin{array}{ll}\text { - words: } & 0 \text { could not make any sound } \\ & 1 \text { could make a sound } \\ 2 & \text { could vocalize using } \\ 3 \text { syllables } \\ 4 \text { could say } 1-3 \text { intelligible words } \\ 5 \text { could say } 3-10 \text { intelligible words } \\ 6 \text { could day } 11-20 \text { intelligible words } \\ 7 \text { could say more than } 20 \text { intelligible words } \\ \text { - sentences: } & 0 \text { could not combine words } \\ & 3 \text { could combine two words } \\ & 6 \text { could combine more than two words }\end{array}$

5) Social abilities reported by parents ( $0-9)$

$\begin{array}{ll}\text { - plays: } & 0 \text { could not play } \\ & 1 \text { could play get and give } \\ & 2 \text { could play at hiding } \\ & 3 \text { could imitate doing housework } \\ & 0 \text { could not attempt to undress } \\ & 2 \text { could attempt to undress } \\ & 3 \text { could attempt to dress } \\ \text { - clothing: } & 0 \text { could not eat unaided } \\ & 1 \text { could eat bread unaided } \\ \text { - eating: } & 2 \text { could drink from cup unaided } \\ & 3 \text { could use spoon unaided }\end{array}$

\section{Results}

\subsection{Growth}

The means of weight, height and head circumference at 1.5 years of age did not differ between the four pairs of groups (table I).

With respect to severity of hypertension among the 58 preterm HT infants, the 31 children in the PRE subgroup were shorter and lighter, and the 11 children in the HCP subgroup were shorter and had smaller heads than the NT preterm children (table IV). Among the 143 full-term HT infants the 43 children in the HCP subgroup were shorter, while 60 children in PIH subgroup were both heavier and longer, and 40 in the PRE subgroup and larger heads than NT children (table IV).

\subsection{Development}

HT preterm and full-term AGA children had lower performances for single developmental items than their controls (table V), but the neu- rodevelopmental scores and developmental milestones did not differ between the groups.

HT preterm SGA children did not differ from their controls. Results among the full-term SGA children varied: there were no differences in the neurodevelopmental scores, but HT SGA children passed more figures through a form box, built a higher tower of cubes but learned to walk later than their controls $(13.2 \pm 2$ months, $\mathrm{p}<0.05$ ).

With respect to severity of hypertension in preterm groups, PRE children had poorer fine motor performance $(p<0.05)$ and visuo-auditory perception $(p<0.05)$ than NT preterm children. In full-term groups PRE and PIH children were better in fine and gross motor performance and in visuo-auditory perception $(p<0.05)$ and in social abilities $(p<0.01)$. The HCP group tended to have the poorest results.

The value of differences in developmental performance between HT and NT preterm children with respect to peri- and neonatal events, IUGR 
Table IV. Means (SD) of weights, heights and head circumferences at birth and at 1.5 years in different hypertension subgroups among preterm and full-term children

\begin{tabular}{|c|c|c|c|c|c|c|c|c|}
\hline & \multicolumn{4}{|l|}{ Preterm } & \multicolumn{4}{|c|}{ Full-term } \\
\hline & PRE & PIH & $\mathrm{CHH}$ & NT & PRE & PIH & $\mathrm{CHH}$ & NT \\
\hline \multicolumn{9}{|l|}{ At birth } \\
\hline $\begin{array}{l}\text { weight }(g) \\
\text { SD }\end{array}$ & $\begin{array}{c}1929 * \\
669\end{array}$ & $\begin{array}{r}2059 \\
546\end{array}$ & $\begin{array}{r}2366 \\
732\end{array}$ & $\begin{array}{r}2309 \\
648\end{array}$ & $\begin{array}{l}3364^{* *} \\
476\end{array}$ & $\begin{array}{r}3533 \\
517\end{array}$ & $\begin{array}{r}3598 \\
500\end{array}$ & $\begin{array}{r}3565 \\
470\end{array}$ \\
\hline $\begin{array}{l}\text { height }(\mathrm{cm}) \\
\text { SD }\end{array}$ & $\begin{array}{c}43.0^{*} \\
3.9\end{array}$ & $\begin{array}{r}44.1 \\
3.7\end{array}$ & $\begin{array}{r}44.8 \\
3.7\end{array}$ & $\begin{array}{r}45.1 \\
3.6\end{array}$ & $\begin{array}{c}50.2^{*} \\
1.8\end{array}$ & $\begin{array}{r}50.6 \\
2.2\end{array}$ & $\begin{array}{r}50.6 \\
2.2\end{array}$ & $\begin{array}{r}50.7 \\
1.9\end{array}$ \\
\hline $\begin{array}{l}\text { head circumference }(\mathrm{cm}) \\
\text { SD }\end{array}$ & $\begin{array}{r}30.6 \\
2.7\end{array}$ & $\begin{array}{r}31.7 \\
2.4\end{array}$ & $\begin{array}{r}31.4 \\
2.7\end{array}$ & $\begin{array}{r}31.6 \\
2.7\end{array}$ & $\begin{array}{r}34.8 \\
1.1\end{array}$ & $\begin{array}{r}34.7 \\
1.2\end{array}$ & $\begin{array}{r}34.7 \\
1.5\end{array}$ & $\begin{array}{r}34.8 \\
1.4\end{array}$ \\
\hline \multicolumn{9}{|l|}{ At 1.5 years } \\
\hline $\begin{array}{l}\text { weight }(\mathrm{g}) \\
\text { SD }\end{array}$ & $\begin{array}{c}10.3^{*} \\
1.5\end{array}$ & $\begin{array}{r}10.8 \\
1.9\end{array}$ & $\begin{array}{r}10.6 \\
7.8\end{array}$ & $\begin{array}{r}11.2 \\
1.4\end{array}$ & $\begin{array}{r}11.2 \\
1.1\end{array}$ & $\begin{array}{c}11.8^{*} \\
1.4\end{array}$ & $\begin{array}{r}11.1 \\
1.1\end{array}$ & $\begin{array}{r}11.4 \\
1.5\end{array}$ \\
\hline $\begin{array}{l}\text { height }(\mathrm{cm}) \\
\text { SD }\end{array}$ & $\begin{array}{l}80.0^{*} \\
3.3\end{array}$ & $\begin{array}{r}80.9 \\
4.6\end{array}$ & $\begin{array}{l}79.3^{* *} \\
2.4\end{array}$ & $\begin{array}{r}82.0 \\
2.9\end{array}$ & $\begin{array}{r}81.8 \\
2.4\end{array}$ & $\begin{array}{c}82.8^{*} \\
2.6\end{array}$ & $\begin{array}{l}81.1^{* *} \\
2.1\end{array}$ & $\begin{array}{r}82.1 \\
1.3\end{array}$ \\
\hline $\begin{array}{l}\text { head circumference }(\mathrm{cm}) \\
\text { SD }\end{array}$ & $\begin{array}{r}47.8 \\
1.7\end{array}$ & $\begin{array}{r}48.0 \\
1.4\end{array}$ & $\begin{array}{c}47.1^{*} \\
0.9\end{array}$ & $\begin{array}{r}48.3 \\
1.4\end{array}$ & $\begin{array}{c}48.5^{*} \\
1.1\end{array}$ & $\begin{array}{r}48.3 \\
1.5\end{array}$ & $\begin{array}{r}48.2 \\
1.2\end{array}$ & $\begin{array}{r}48.2 \\
1.5\end{array}$ \\
\hline
\end{tabular}

${ }^{*} \mathrm{p}<0.05 ;{ }^{* *} \mathrm{p}<0.01 ;{ }^{* * *} \mathrm{p}<0.001$, Kruskal-Wallis and Mann-Whitney tests, preterm subgroups are compared with the preterm NT group and full-term subgroups with the full-term NT group.

PRE = pre-eclampsia

$\mathrm{PIH}=$ hypertension induced by pregnancy without PRE

$\mathrm{CHH}=$ chronic hypertension without PRE

Table V. Differences in developmental items: the numbers refer to percentages of children in hypertensive (HT) and normotensive (NT) group pairs

\begin{tabular}{|c|c|c|c|c|c|c|c|c|}
\hline & \multicolumn{2}{|c|}{ Preterm AGA } & \multicolumn{2}{|c|}{ Preterm SGA } & \multicolumn{2}{|c|}{ Full-term AGA } & \multicolumn{2}{|c|}{ Full-term SGA } \\
\hline & $\begin{array}{l}\mathrm{HT} \\
\mathrm{n}=33\end{array}$ & $\begin{array}{l}\mathrm{NT} \\
\mathrm{n}=111\end{array}$ & $\begin{array}{l}\mathrm{HT} \\
\mathrm{n}=25\end{array}$ & $\begin{array}{l}\mathrm{NT} \\
\mathrm{n}=17\end{array}$ & $\begin{array}{l}\mathrm{HT} \\
\mathrm{n}=125\end{array}$ & $\begin{array}{l}\mathrm{NT} \\
\mathrm{n}=121\end{array}$ & $\begin{array}{l}\mathrm{HT} \\
\mathrm{n}=18\end{array}$ & $\begin{array}{l}\mathrm{NT} \\
\mathrm{n}=54\end{array}$ \\
\hline $\begin{array}{l}\text { Building tower } \\
\leq 4 \text { cubes }\end{array}$ & 67 & 69 & 84 & 93 & 62 & 67 & 50 & 80 \\
\hline $\begin{array}{l}\text { Putting no objects } \\
\text { into a form box }\end{array}$ & 66 & 67 & 88 & 88 & 69 & 65 & $50^{*}$ & 81 \\
\hline Grasp $^{1}$ & $76^{*}$ & 42 & 75 & 80 & 62 & 66 & $56^{*}$ & 74 \\
\hline Not drawing & 0 & 5 & 4 & 13 & 1 & 0 & $0^{*}$ & 8 \\
\hline $\begin{array}{l}\text { Not naming any } \\
\text { coloured picture }\end{array}$ & $78^{*}$ & 53 & 71 & 60 & 62 & 59 & 61 & 57 \\
\hline $\begin{array}{l}\text { Not pointing to any } \\
\text { DDST picture }\end{array}$ & 53 & 45 & 68 & 67 & $62 * * *$ & 37 & 35 & 45 \\
\hline $\begin{array}{l}\text { No attempt to } \\
\text { dress himself }\end{array}$ & $46^{* *}$ & 23 & 33 & 63 & 36 & 27 & $44^{*}$ & 17 \\
\hline
\end{tabular}

${ }^{*} \mathrm{p}<0.05 ;{ }^{* *} \mathrm{p}<0.01 ; * * * \mathrm{p}<0.001 ;$ chi-squared test

${ }^{1}$ top and/or tong grasp or does not use index finger to stabilise the pen. 
and sex was analysed by stepwise discriminant analysis. In preterm children, $15 \%$ of the between-group differences were associated with maternal blood pressure. The majority were caused by IUGR and only $1 \%$ by neurological findings. In full-term children only $4 \%$ of the between-group differences were assoicated with maternal blood pressure, mainly from reduced neonatal optimality of HT children, and less than $1 \%$ from neurological findings. The differences correctly classified $70 \%$ of the children in each analysis.

\subsection{Neurologically abnormal and suspect chil- dren}

The numbers of neurologically suspect/abnormal children were highest in both preterm SGA groups, being $36 \%$ in the HT and $41 \%$ in the NT group (figure 1), and with respect to severity of hypertension highest in the preterm PRE group, at $42 \%$ (figure 2). All three groups differed significantly from the NT full-term AGA group $(\mathrm{p}<0.05)$.

\section{Discussion}

Determining the effect of pregnancy hypertension on a child's development is difficult, because a number of confounding perinatal factors exist, such as prematurity and intrauterine growth retardation $[11,15,23]$. However, this problem can largely be eliminated by equalising the index and control groups with respect to these factors and using statistical methods that consider all the variables equally and simultaneously. The use of optimality scores is a widely accepted solution for controlling the association between neurological development and obstetric and neonatal background factors, because most often neurological morbidity is the result of a cluster of complications rather than one $[8,20]$.

It has been shown that maternal hypertension, even pre-eclampsia, does not affect postnatal growth [18]. In the present study no difference was found between HT and NT pairs of groups, but both preterm and NT full-term SGA groups were retarded compared with AGA groups. Thus, irrespective of aetiology IUGR predicts poor postnatal growth better than maternal hypertension. However, when the severity of hypertension was taken into account, clear catchup growth had occurred in the full-term, but not

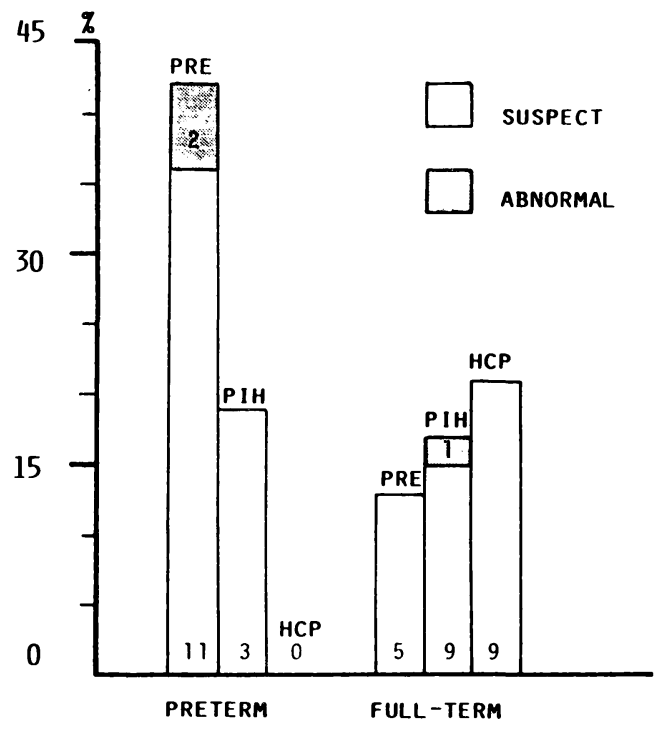

Figure 1. Proportions of neurologically suspect and abnormal children in hypertensive (HT) and normotensive (NT) pairs of groups at 1.5 years. Numbers of children are marked in the bars.

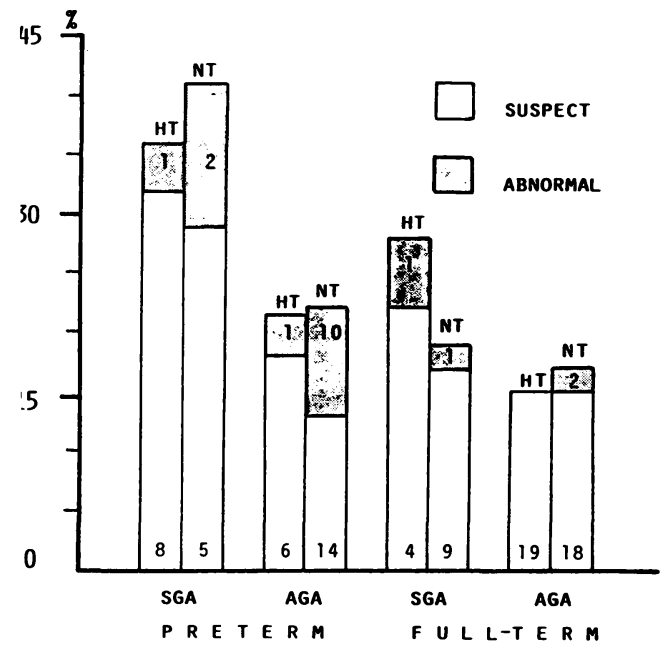

Figure 2. Proportions of neurologically suspect and abnormal children in hypertensive subgroups at $\mathbf{1 . 5}$ years. Numbers of children are marked in the bars.

in the preterm, PRE group. Catch-up growth has been reported by others in an asymmetric type of IUGR, which is typical of hypertensive pregnancy $[2,12]$ and which occurs late in pregnancy. In preterm groups growth failure started earlier and the pathogenesis was more complex. 
To speculate further, fathers of the preterm PRE group were small compared with those of the NT group.

Maternal hypertension caused developmental differences, which were most evident in preterm and full-term AGA children. However, problems brought about by IUGR masked most of these differences. Both preterm SGA groups were generally worse off than the AGA groups. Thus, IUGR is a significant risk factor for the preterm child regardless of whether or not the pregnancy is hypertensive. When the baby reaches term, the significance of hypertension and IUGR diminishes and both full-term SGA children develop similarly to AGA children, as has also been shown elsewhere [5].

Despite the developmental delay major abnormalities were no more frequent among HT groups than among the controls. Good antenatal care and appropriate timing of delivery most likely account for this, and neurological sequelae anyway are clearly too rough measures of the influence of a single obstetric factor. On the other hand, less severe neurological abnormalities can only be detected with certainty later in childhood [11].

\begin{abstract}
To determine the effect of maternal hypertension additional to intrauterine growth retardation and prematurity, the growth and development of 58 preterm and 143 full-term children of hypertensive mothers was evaluated at 1.5 years of corrected age. The results were compared with 128 preterm and 175 full-term children of normotensive mothers, respectively. Children with intrauterine growth retardation were examined separately from those without. Growth was sim-
\end{abstract}

Developmental delay is related to the severity of hypertension directly in preterm and inversely in full-term infants, as are growth measurements at 1.5 years. The duration of mild hypertension is also important, because preterm HCP children are also shorter and lighter than the controls whereas PIH children are not. In pregnancy reaching term the duration of hypertension is even more singificant than the severity of the short-lasting disease: both the developmental items and the growth measurements of the fullterm PRE and PIH groups were better, but those of the full-term HCP group worse than in the respective NT groups. However, except for the preterm PRE group developmental differences were within normal limits.

The present data show that the outcome of a child with maternal hypertension is good. Developmental differences do exist between $\mathrm{HT}$ and NT children at the age of 1.5 years, but those clearly at developmental risk are preterm children born to pre-eclamptic mothers and preterm children with IUGR irrespective of aetiology. The lack of increased neurological sequelae in HT children stresses their uselessness as parameters of child outcome and the importance of good peri- and neonatal care.

ilar between index and control pairs of groups but was delayed in preterm children born to pre-eclamptic mothers. Developmental differences were found between the index and control groups, but the only children clearly at developmental risk were those born prematurely to pre-eclamptic mothers, and those born prematurely with IUGR irrespective of aetiology. Generally the outcome of children of hypertensive mothers was good.

Keywords: Child, development, growth, pregnancy hypertension.

\section{Zusammenfassung}

Wachstum und Entwicklung von 11/2-jährigen Kindern bei mütterlichem Hypertonus in der Schwangerschaft In der vorliegenden Studie untersuchten wir den Einfluß eines mütterlichen Hypertonus (RR-Werte über $140 / 90 \mathrm{mmHg}$ ) auf die Entwicklung und das Wachstum des Kindes mit dem korrigierten Alter von 1,5 Jahren \pm 2 Wochen. Die zwischen 1984 und 1986 in der Universitätsklinik Kuopio geborenen 504 in die Studie einbezogenen Kinder wurden mit dem modifizierten "Denver Developmental Screening Test" untersucht.
Sowohl einzelne Entwicklungsparameter wurden berücksichtigt wie auch fünf Scores zur Beurteilung der Entwicklung benutzt (Tab. III). Die 186 frühgeborenen Kinder (Gestationsalter unter 37 Wochen) wurden separat von den 318 reifgeborenen Kindern untersucht. In beiden Gruppen wurde eine Unterscheidung vorgenommen zwischen Kindern mit adäquatem Geburtsgewicht (AGA) und Small-for-date-Kindern (SGA). Die Kinder hypertensiver (HT) Mütter wurden mit denen normotensiver (NT) Mütter verglichen. 
In den vier Gruppen (frühgeborene AGA-Kinder, frühgeborene SGA-Kinder, reifgeborene AGA-Kinder und reifgeborene SGA-Kinder) unterschieden sich die Mittelwerte von Gewicht, Größe und Kopfumfang in der Untersuchungs- und Kontrollgruppe nicht (Tab. I). Frühgeborene und reifgeborene AGA-Kinder aus den HT-Gruppen hatten geringere Fähigkeiten als ihre Kontrollen, wenn einzelne Entwicklungsparameter berücksichtigt wurden (Tab. V), jedoch waren die Gesamtscores und wichtigen Schritte bei der Beurteilung der neurologischen Entwicklung zwischen den Gruppen vergleichbar. Frühgeborene SGA-Kinder unterschieden sich nicht von den Kontrollen. Reifgeborene SGA-Kinder schnitten in einigen Punkten besser ab, lernten jedoch später laufen als die zugehörigen Kontrollkinder.

Die Bedeutung der Entwicklungsunterschiede zwischen Untersuchungs- und Kontrollgruppe wurde durch eine schrittweise Diskriminanz-Analyse überprüft. Dabei wurden eine IUGR, das Geschlecht und Hintergrundfaktoren, die bei prä- und intrapartalen sowie neonatalen Zwischenfällen reduzierte Scores bedingen, berücksichtigt. Unter Frühgeborenen waren $15 \%$ der Unterschiede zwischen den HT- und NT-Gruppen durch den Blutdruck bedingt. Eine IUGR in der HTGruppe war viel häufiger ursächlich für den Unterschied. Unter den Reifgeborenen waren nur 4\% der
Unterschiede mit dem mütterlichen Blutdruck assoziiert; einen größeren Anteil hatte eine erhöhte neonatale Morbidität in der HT-Gruppe.

Unter den Frühgeborenen beobachteten wir starke Verzögerungen in Wachstum und Entwicklung bei Kindern präeklamptischer Mütter. Bei den Reifgeborenen waren Kinder von Frauen mit chronischem Hypertonus verzögert. Die reifen Kinder präeklamptischer Mütter zeigten ein gutes Aufholwachstum und eine altersentsprechende Entwicklung mit 1,5 Jahren.

Die Anzahl der Kinder mit neurologischen Anomalien und Fähigkeiten unterhalb der 10-er Perzentile der reifgeborenen AGA-Kontrollgruppe war am höchsten in der frühgeborenen SGA-Untersuchungs- und Kontrollgruppe (Abb. 1) und in der frühgeborenen Gruppe präeklamptischer Mütter (Abb. 2).

Es fanden sich Entwicklungsunterschiede zwischen Kindern von HT- und Nt-Müttern, jedoch wurde meistens eine normale Variationsbreite nicht überschritten. Frühgeborene Kinder präeklamptischer Mütter und Kinder mit IUGR, unabhängig von der Ätiologie, hatten deutliche Entwicklungsverzögerungen. Im übrigen war das Outcome eines Kindes bei Vorliegen einer mütterlichen Hypertension gut, was eine gut antenatale Versorgung und einen adäquaten Entbindungszeitpunkt widerspiegelt.

Schlüsselwörter: Entwicklung, Kind, Schwangerschaftshypertonus, Wachstum.

\section{Résumé}

Croissance et développement a l'âge d'1,4 an chez les enfants de mères hypertendues

L'objectif de cette étude est d'évaluer l'effet de l'hypertension maternelle (pression sanguine supérieure à $140 / 90 \mathrm{~mm} \mathrm{Hg}$ ) sur le développement et la croissance d'un enfant de 1,5 an + ou -2 semaines d'âge corrigé. L'auteur a éxaminé à l'aide du test de dépistage développemental modifié de Denver l'ensemble des 504 enfants nés à l'Hôpital Central de l'Université de Knopie de 1984 à 1986. On a utilisé des items développementaux uniques et cinq scores développementaux (tableau III). Les 186 enfants prématurés (âge gestationnel inférieur à 37 semaines) ont été éxaminés séparément des 318 enfants à terme, et pour chaque groupe approprié quant à l'âge gestaionnel (AGA) les enfants ont été éxaminés séparément de ceux qui étaient petits pour l'âge gestationnel (SGA). On a comparé les enfants nés de mères hypertendues (HT) avec les enfants respectifs nés de mères normotendues (NT).

Il n'y a pas de différence pour les moyenne de poids, de taillet et de circonférence céphalique entre les enfants étudiés et les contrôles que ce soit dans les groupes de prématurés AGA, de prématurés SGA, d'enfants à terme AGA ou à terme SGA, d'enfants à terme AGA ou à terme SGA (tableau I). Les enfants AGA prématurés et à terme des groupes HT ont descapacités moindres au niveau des items développemen- taux uniques que celles des contôles (tableau V), mais les scores neurodeveloppementaux ne sont pas différents entre les groupes. Les enfants prématurés SGA étudiés ne diffèrent pas de leurs contrôles. Les enfants à terme SGA étudiés s'y prennent mieux pour certains items développementaux mais apprennent à marcher plus tardivement que ceux du groupe contrôle respectif.

On a examiné, par une analyse discriminante multivariée en fontion de la présence d'l RCIU, du sexe et de facteurs sous-jacents, exprimés en tant que scores d'optimalité des facteurs prépartum, perpartum et néonataux, la valeur des différences développementales entre les enfants étudiés et les conrôles. Parmi les prématurés, 1,5\% des différences entre les groupes HT and NT sont liés à la pression sanguine maternelle et sont le plus souvent secondaires à une augmentation des RCIU dans le groupe HT. Pour les enfants à terme, seulement $4 \%$ des différences sont liées à la pression sanguine maternelle, et sont le plus souvent provoquées par une élévation de la morbidité néonatale dans le groupe HT.

Parmi les enfants prématurés, la croissance postnatale et le dévelppement les moins bons ont été observés chez les enfants nés de mères pré-éclamptiques, et parmi les enfants à terme chez ceux nés de mères avec une hypertension chronique. Les enfants à terme nés 
de mères pré-éclamptiques montrent à 1,5 an une bonne récupération de la croissance et un bon développement.

Le nombre d'enfants avec des anomalies neurologiques et avec des capacités inférieures au 10ème percentile de celles du groupe contrôle AGA à terme est plus important chez les enfants étudiés prématurés et chez les groupes contrôles (Figure 1) ainsi que parmi le groupe prématuré avec préeclampsie (Figure 2).
On a trouvé des différences développementales entre les enfants nés de mères HT et NT, mais le plus souvent elles se situent dans les limites normales. Il est clair que les enfants prématurés nés de mères pré-éclamptiques et ceux avec un retard de croissance intrautérin quelle qu'en soit l'étiologie sont à risques de troubles développementaux. D'un autre côté, l'évolution d'un enfant dont la mère est hypertendue est bonne, ce qui témoigne des soins anténataux de qualité et un choix du moment de l'accouchement approprié.

Mots-clés: Croissance, developpement, enfant, hypertension gravidique.

\section{References}

[1] Brazy JE, JK GRIMm, VA LitTLE: Neonatal manifestations of severe maternal hypertension occurring before the thirty-sixth week of pregnancy. J Pediatr 100 (1982) 265

[2] CooK LN: Intrauterine and extrauterine recognition and management of deviant fetal growth. Pediatr Clin North Am 24 (1977) 431

[3] Frankenburg WK, JB Dodds, AW Fandal, E KAZUK, M CoHRS: Denver Developmental Screening Test: Reference Manual. University of Colorado Medical Center, Denver 1975

[4] Hagberg G, B Hagberg, I Olow: The changing panorama of cerebral palsy in Sweden 19541970. Acta Paediatr Scand 65 (1976) 403

[5] HomQvist P, E INGEMARSSON, I INGEMARSSON: Intra-uterine growth retardation and gestational age. Acta Obstet Gynecol Scand 65 (1986) 633

[6] ILLINGWORTH RS: The development of the infant and young child. Normal and abnormal. 8th ed. Churchill Livingstone, Edinburgh 1983

[7] KITCHEN WH, VYH YU, AA ORGILL, et al.: Collaborative study of very-low-birth-weight infants. Am J Dis Child 137 (1983) 555

[8] Kyllerman M, C HAGBerG: Reduced optimality in pre- and perinatal conditions in a Swedish newborn population. Neuropediatrics 14 (1983) 37

[9] LuNDBERG A: "The drawing test" - a tool for assessment of arm-hand function in children of 1-3 years of age. Neuropädiatrie 10 (1979) 29

[10] Martikainen MA, EM AiraKsinen, KM HeINONEN, MK CASTREN: The neurological condition of the newborn infant with maternal hypertension examined at term. Early Hum Dev 16 (1988) 107

[11] Michelsson K, E Lindahl, M Parre, M HelenIUS: Nine-year follow-up infants weighing $1500 \mathrm{~g}$ or less at birth. Acta Paediatr Scand 73 (1984) 835

[12] Miller HC: Perinatal factors affecting intrauterine growth retardation. Clin Perinatol 12 (1985) 307
[13] Mutch LMM, VA MOAR, MK OUNSTED, CWG REDMAN: Hypertension during pregnancy, with and without specific hypotensive treatment. I. Perinatal factors and neonatal morbidity. Early Hum Dev 1 (1977) 47

[14] Mutch LMM, VA Moar, MK Ounsted, CWG REDMAN: Hypertension during pregnancy, with and without specific hypotensive treatment. II. The growth and development of the infant in the first year of life. Early Hum Dev 1 (1977) 59

[15] Neligan GA, I Kolvin, DMcI Scott, RF GaRSIDE: Born too soon born too small. A follow-up study to seven years of age. Spastic International Medical Publications London: Williams Heinemann Medical Books. JB Lippincott, Philadelphia 1976

[16] NoRusis MJ: Advanced statistics guide. McGraw Hill Book Company, Chicago 1985

[17] OUNSTEd MK, VA MOAR, FJ Good, CWG ReDMAN: Hypertension during pregnancy with and without specific treatment; the development of the children at the age of four years. Br J Obstet Gynaecol 87 (1980) 19

[18] OUNSTED M, V MOAR, A Scotr: Growth in the first four years: III. The effects of maternal factors associated with small-for-dates and large-fordates pregnancies. Early Hum Dev 7 (1982) 347

[19] PReChTL HFR: Neurological findings in newborn infants after pre- and paranatal complications. In: JONXIS JHP, HKA VISSER, JA TROELSTRA: Aspects of prematurity and dysmaturity. Nutricia symposium 1967. Stenfert Kroese, Leiden 1968

[20] Rosen MG, RM BILENKER, K ThOMPSON: Assessment of developmental time periods and risks of brain damage in the fetus and neonate. J Reprod Med 31 (1986) 297

[21] Sibai BM, GD Anderson, TN Abdella, JH McCuBBIN, PV DiLts: Eclampsia. III. Neonatal outcome, growth and development. Am J Obstet Gynecol 146 (1983) 307 
[22] SIEgel S: Nonparametric Statistics for the Behavioral Sciences. McGraw Hill International Book Company, Tokyo 1956

[23] Stave U, C Ruvalo: Neurological development in very-low-birthweight infants. Application of a standardized examination and Prechtl's optimality concept in routine evaluations. Early Hum Dev 4 (1980) 229

[24] SVenningsen NW, H Liedholm, A Aberg: Hypertension in pregnancy and the infant. Acta Obstet Gynecol Scand, suppl. 118 (1984) 103

[25] SZYmonovicz W, VYH YU: Severe pre-eclampsia and infants of very low birth weight. Arch Dis Child 62 (1987) 712
[26] Winer EK, NA Tejani, VL Atluru, R DiGIUSEPPE, LG BOROFSKY: Four- to seven-year evaluation in two groups of small-for-gestational age infants. Am J Obstet Gynecol 143 (1982) 425

Received January 24, 1989. Revised May 5, 1989. Accepted June 21, 1989.

Anneli Martikainen, MD

Department of Paediatrics

Kuopio University Central Hospital

P. Box 6

70211 Kuopio

Finland 


\section{New Developments in Biosciences}

Volume 1:

\section{LH-RH and its Analogues}

Fertility and Antifertility Aspects

Edited by Manfred Schmidt-Gollwitzer $\dagger$

Co-Editor: Rosemarie Schley

1985. $17 \times 24 \mathrm{~cm}$. X, 357 pages. With 174 illustrations and

54 tables. Paperback DM 98,- ISBN $311010055 X$

Volume 2:

\section{A Modern Approdch to the Perimenopausal Years}

Edited by Robert Greenblatt

Co-Editor: Renate Heithecker

1986. $17 \times 24 \mathrm{~cm}$. VI, 256 pages. With 62 illustrations and

44 tables. Paperback DM 98,- ISBN 3110109379

Volume 3:

Antiandrogen-estrogen therapy in signs of androgenization

Editor: Adolf E. Schindler

1987. $17 \times 24 \mathrm{~cm} .244$ pages. With 101 illustrations and

59 tables. Paperback DM 98,- ISBN 3110112256

Volume 4:

Endocrine Management of Prostatic Cancer

Editor: Herbert Klosterhalfen

1988. $17 \times 24 \mathrm{~cm}$. VI, 138 pages. With 45 illustrations and numerous tables. Paperback DM 48,- ISBN 3110115131

Volume 5:

\section{Prostatic Hyperplasia}

Etiology, Surgical and Conservative Management

Editors: R. Ackermann and F. H. Schröder

1989. $17 \times 24 \mathrm{~cm}$. X, 154 pages. With 44 illustrations.

Paperback DM 58,-- ISBN 3110118653

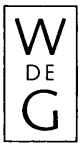

\section{de Gruyter · Berlín · New York}

